\title{
Costly tolerance
}

\begin{tabular}{|c|c|}
\hline $\begin{array}{l}\text { Author: } \\
\text { Leo Koffeman }\end{array}$ & \\
\hline $\begin{array}{l}\text { Affiliations: } \\
{ }^{1} \text { Church Polity } \\
\text { Ecumenism at } \\
\text { Theological U } \\
\text { Amsterdam, T } \\
\text { (emeritus) }\end{array}$ & $\begin{array}{l}\text { and } \\
\text { the Protestant } \\
\text { iversity, } \\
\text { he Netherlands }\end{array}$ \\
\hline $\begin{array}{l}{ }^{2} \text { Department } \\
\text { History and } \mathrm{Cl} \\
\text { Faculty of The } \\
\text { University of } \\
\text { South Africa }\end{array}$ & $\begin{array}{l}\text { f Church } \\
\text { urch Polity, } \\
\text { ology, } \\
\text { retoria, }\end{array}$ \\
\hline $\begin{array}{l}\text { Research proj } \\
\text { registration: } \\
\text { Project leade } \\
\text { Merwe } \\
\text { Project numb }\end{array}$ & $\begin{array}{l}\text { ect } \\
\text { : J.M. van der } \\
\text { er: } 02383810\end{array}$ \\
\hline $\begin{array}{l}\text { Description: } \\
\text { Prof. Dr Leo K } \\
\text { participating i } \\
\text { project, 'Ecum } \\
\text { Polity', directe } \\
\text { Dr Johan van } \\
\text { Department o } \\
\text { History and Cr } \\
\text { Faculty of The } \\
\text { University of }\end{array}$ & $\begin{array}{l}\text { offeman is } \\
\text { the research } \\
\text { enical Church } \\
\text { d by Prof. } \\
\text { der Merwe, } \\
\text { f Church } \\
\text { uurch Polity, } \\
\text { ology, } \\
\text { retoria. }\end{array}$ \\
\hline $\begin{array}{l}\text { Correspondin } \\
\text { Leo Koffeman } \\
\text { ljkoffeman@p }\end{array}$ & $\begin{array}{l}\text { g author: } \\
\text { thu.nl }\end{array}$ \\
\hline $\begin{array}{l}\text { Dates: } \\
\text { Received: } 09 \\
\text { Accepted: } 28 \\
\text { Published: } 08\end{array}$ & $\begin{array}{l}\text { ec. } 2015 \\
\text { lan. } 2016 \\
\text { July } 2016\end{array}$ \\
\hline $\begin{array}{l}\text { How to cite th } \\
\text { Koffeman, L.J. } \\
\text { tolerance', HT } \\
\text { Studies/Theol } \\
72(1) \text {, a3282, } \\
\text { org/10.4102/l }\end{array}$ & $\begin{array}{l}\text { is article: } \\
\text { 2016, 'Costly } \\
\text { S Teologiese } \\
\text { ggical Studies } \\
\text { http://dx.doi. } \\
\text { tts.v72i1.3282 }\end{array}$ \\
\hline $\begin{array}{l}\text { Copyright: } \\
\text { (c) 2016. The } \\
\text { Licensee: AOS } \\
\text { is licensed un } \\
\text { Creative Comr } \\
\text { Attribution Lic }\end{array}$ & $\begin{array}{l}\text { ISthors. } \\
\text { IS. This work } \\
\text { der the } \\
\text { nons } \\
\text { ense. }\end{array}$ \\
\hline Read online: & \\
\hline 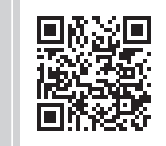 & $\begin{array}{l}\text { Scan this QR } \\
\text { code with your } \\
\text { smart phone or } \\
\text { mobile device } \\
\text { to read online. }\end{array}$ \\
\hline
\end{tabular}

Tolerance is an aspect of the balance between power and freedom. This contribution starts from a decision taken by the general synod of the Reformed Churches in the Netherlands, in 1914, on the issue of church members who did not recognise infant baptism. The synod decided that - on certain conditions - 'tolerance can be practiced' towards such members. This contribution analyses and evaluates this decision, with particular attention for the distinction made between fundamental and non-fundamental faith issues. It shows how this decision is related to the broader context of early twentieth century political life in the Netherlands (the 'Pacification of 1917 '), and it concludes with some thoughts on the costliness of true tolerance.

\section{Introduction}

If I remember well, the first time I met Graham Duncan was at the occasion of my study leave, in February 2010. At the time I was exploring the possibilities of publishing an 'Introduction to church polity' in English, and therefore I was happy with the opportunity to have a discussion with a colleague who, although first of all a church historian, was also responsible for teaching in the field of church polity, particularly in terms of making future ministers of the Uniting Presbyterian Church in Southern Africa acquainted with its church order.

In an early morning discussion, we shared our concerns with regard to the role of church discipline: under circumstances, church order regulations - particularly but not exclusively with regard to church discipline - can function as a means of oppression. They can be patronising, if not legitimising sheer spiritual violence. Graham gave me a copy of an interesting article of his that was about to be published (see Duncan 2010a), and he added some personal experiences he had had during his early years of ministry in the church in South Africa. He would also refer to these experiences in a second article on discipline he was writing at the time:

Then, in 1978, I came to South Africa to be ordained a minister in the Bantu Presbyterian Church of South Africa, where discipline was viewed in a very different manner. Here it was largely a matter of punishing young single girls who had become pregnant as the result of a form of immaculate conception where no evidence was ever provided of male involvement in the matter. These girls would inevitably be excluded from the sacrament for a period and deprived of its saving graces though still required to pay their dues to the Deacons' Court. (Duncan 2010b:1)

At least partly as a consequence of Duncan's experiences as well as of his appraisal of the original intention of church discipline in Reformation time, the Presbyterian church order stipulations with regard to discipline had been reconsidered in the early 1980s. The encounter with Duncan made me more aware of the use of power in church polity. In the personal notes I made afterwards I wrote: 'In my book I will have to go more deeply into the role of power in church polity, not least with regard to the way it is handled'. It became part of the background of my reflections on 'the power issue' in the book that finally resulted from my study leave (see Koffeman 2014, esp. 66-68).

Afterwards, the relation between power and freedom in church polity has continued to draw my attention. We may not like to speak about 'power' in the church too much (and for good reasons), but from a sociological perspective it is obvious that power plays a role in the church - as in any other part of society: it can be, and usually is, legitimate power, based on authority as conferred in church order regulations, but it can even be illegitimate. It is from this perspective that I use the concept of power in this contribution. Also in the church, decisions have to be taken, and such decisions have an impact on people that depend on them. At the same time, freedom is key to life in any community, including churches, or rather particularly in churches. For churches may live with a Gospel that is reflected in the well-known words of St. Paul: 'Where the Spirit of the Lord is, there is freedom' (2 Cor. 3, 17 NIV). Of course, a biblical understanding of freedom (cf. Gl. 5, 1 and 13ff.) is not equivalent to what freedom stands for in any political ideology. But, again from a sociological perspective, also in church life a balance between power and freedom has to be 
found again and again, in daily life, in formalised policies, in procedures based on valid legislation in church orders, and also in legisprudence, that is the process of drafting new or revising existing church order stipulations.

One aspect of the balance between power and freedom concerns the degree of tolerance that is possible within a particular community. Tolerance can be seen as the willingness of those in power to abandon the use of power in favour of the freedom of those that are subject to it; in this context 'power' has to be understood in its widest sense: it does not only refer to formal powers but also to, for instance, the power that is given with being part of a majority in society, or even to the options someone has to use violence. On a formal level in political life, tolerance is an aspect of the constitutional tension between governance, jurisdiction, and human rights. The core of human rights is that it puts limitations to the use of power by the authorities. Governance and jurisdiction in themselves can only function if people are obedient, whereas human rights imply that people have fundamental freedoms. At best, civil legislation is such that obedience and freedom are kept in balance, so that obedience can be experienced as rooted in freedom. And at best, those in power know how to maintain that balance in their governing practice.

It is similar in the church. For instance, in church discipline the competent bodies - like ecclesial courts - have a certain discretionary power that makes it possible to take disciplinary action against someone for his or her behaviour, attitude, or even conviction, or not to do so and to tolerate such deviant actions or views. But the degree of discretionary power is limited by church legislation: it should not become equal to arbitrariness; justice has to be done. Tolerance is not only a matter of attitude or behaviour, but also a matter of rules. It is a sensitive issue in all kinds of societies, but it certainly is in religious communities like churches - as it is obvious from the example presented by Graham Duncan above. So, to what extent and under which conditions is tolerance acceptable or even mandatory in church life?

In March 2015, I attended an interfaith conference called Costly Tolerance that was held at the Muslim university UIN Sunan Kalijaga in Yogyakarta (Indonesia). Indonesian and Dutch scholars, both Christians and Muslims, shared their experiences and views with regard to this theme, from philosophical, systematic-theological, Biblical, and Quranic as well as historical and empirical perspectives. Practitioners from the grassroots level told stories about success and failure in realising tolerance in conflict areas.

I was asked to contribute to the issue of tolerance from a church polity perspective, and my research again made me contemplate the role of power in the church: how do those in power deal with the freedom of those who depend on their decisions? That is what tolerance is all about. In considering this question I realised that the term 'tolerance' was central to a decision taken by the church I belong to, exactly one century ago, in a time that tolerance was certainly not seen as a hot issue in the Netherlands. In 1914, the general synod of the Reformed Churches in the Netherlands took a decision with regard to the question of how to deal with internal diversity. Its core was: under certain conditions a kind of tolerance can be exercised within the church, instead of using the church order instruments of discipline. This stimulated me to focus on research from a church history perspective, although I am not a church historian but a systematic theologian. My intention - in my contribution to the aforementioned conference as I am working up in this article - is to analyse the synodical decision, including an effort to understand it in its social and political context. After all, in the same years an important political step was taken to soften tensions between the four main political movements, and to enhance a kind of political tolerance. What can we learn from both the ecclesial and the political developments at that time with a view to understanding the importance of tolerance today?

\section{Background information}

Let me first give some basic information about the aforementioned decision of the general synod. It concerns the Reformed Churches in the Netherlands, at that time the third largest denomination in the Netherlands. In 1914, the vast majority of Dutch people (96\%) belonged to a Christian church, at least nominally, and usually including a high degree of active participation. About half of them were Roman Catholics, and half of them were Protestants. Roman Catholics and Protestants would mutually have a negative picture of the other community. Within Protestantism we could - and still can - find many different churches; among them the Netherlands Reformed Church (NRC, the former national church) was the largest in terms of membership, and the Reformed Churches in the Netherlands (RCN), born from two separations from the former, was the second largest, including about $7 \%$ of the Dutch population. In the meantime, in 2004, NRC and RCN have reunited into the Protestant Church in the Netherlands, uniting at the same time with a third church, the Evangelical Lutheran Church in the Kingdom of the Netherlands (see Plaisier \& Koffeman 2014).

A century ago, the RCN was a very orthodox and strict church: its reason of existence was exactly its opposition to theological liberalism as manifest in the Netherlands Reformed Church in the nineteenth century. Therefore, uniformity in terms of faith convictions and lifestyle was seen as very important in the $\mathrm{RCN}$, and church discipline played a vital role in maintaining uniformity in ethics and doctrine. The sum total of shared faith convictions was usually referred to as 'the confession of the church' or 'the Reformed confession'. In order to maintain this theological and confessional unity, the church could take disciplinary measures, one of them being the refusal to admit someone to Holy Supper if he or she would not agree with the Reformed confession. The Church Order in force, basically the so-called 'Dordt Church Order' (cf. Van Lieburg 2014), attributed this responsibility (power) to the local church council with the following stipulation:

None shall be admitted to the Lord's Supper except those who, according to the usage of the Church to which they unite 
themselves, have made Confession of Religion, besides being reputed to be of a godly conversation, without which also those who come from other Churches shall not be admitted. (Dordt Church Order, Art. 61)

In fact, the RCN was a national federation of hundreds of local communities, united in one common set of convictions and ethical values, and conservative in nature. The general synod, meeting every 2 or 3 years, was the national governing body of the RCN, and was authorised to decide on issues of doctrine. So, its core concern was to maintain the unity and uniformity of the RCN. Its agenda would include several issues as brought up by the local or regional governing bodies of the church.

The synodical decision I want to focus on was taken in November 1914. In fact, the synod met a few months after the beginning of the First World War. However, the Dutch army was mobilised, but it did not take part in the hostilities. The Netherlands maintained its neutrality throughout the war.

\section{The issue at stake}

The decision taken in 1914 regards the issue of infant baptism. The question raised by one of the regional bodies, known as 'the particular synod of Friesland-Southern area', was this: does someone who agrees with the Reformed confession in all respects, but who rejects infant baptism, who however promises not to propagate this opinion and who is testified to live a pious life, qualify for admission to Holy Supper, according to article 61 of the Church Order? (see Acta 1912-1914:39). The general synod of the RCN decided as follows, taking 'tolerance' as its key term:

The Reformed Churches in the Netherlands have always been of the opinion that - consistent with the example of the apostolic church - tolerance can be exercised with respect to members of the congregation that err in good faith regarding any issue of doctrine, provided

that this does not concern any fundamental issue of truth,

that those who err are ready to have themselves better instructed, and

that they promise not to propagate their opinion,

in which case it is, of course, self-evident that such members of the congregation will not be eligible for any office.

\section{Analysis}

Some comments have to be made in order to assess the significance of this decision. In this respect, we have to take into consideration the Report of an Advisory Committee as presented to the general synod, which includes the argumentation underlying this decision (see Report 1914).

To begin with, it might be a bit too optimistic to state that the church 'has always been of the opinion that tolerance can be exercised...'. For centuries, tolerance has certainly not been characteristic of the churches, and - from our perspective! that was certainly the case a century ago.
The reference to 'the example of the apostolic church' serves as a biblical foundation of this decision. The Report refers to four biblical texts (quoted here from NIV):

- Romans 14:1: 'Accept the one whose faith is weak, without quarrelling over disputable matters'.

- Romans 15:1-2: '[We who are strong ought to bear with the failings of the weak and not to please ourselves.] Each of us should please our neighbours for their good, to build them up'.

- Philippians 3:15: 'All of us, then, who are mature should take such a view of things. And if on some point you think differently, that too God will make clear to you'.

- Hebrew 5:11f: 'We have much to say about this, but it is hard to make it clear to you because you no longer try to understand. In fact, though by this time you ought to be teachers, you need someone to teach you the elementary truths of God's word all over again. You need milk, not solid food!'.

It is obvious, particularly in the quote from Hebrews 5, that tolerance is put in a framework of inequality: we are 'strong', but we tolerate the 'weak'. In Romans 14 and 15, we find a different atmosphere. Paul fully recognises that the issues at stake (like religious dietary regulations) are deemed very important by the 'weak', but he sees them as basically irrelevant, and that's why he can agree to disagree on this. As far as we can speak of tolerance here, it is not a kind of tolerance that is characterised by an understanding that different people with different opinions would have the same position and rights. This tolerance is a matter of goodwill, not a matter of equal rights. Insofar, one could see behind this a patronising attitude.

In the synodical decision, tolerance is conditioned. As a consequence of this understanding of the biblical concept of the strong and the weak, the decision of the synod presents four conditions that considerably limit this appeal to tolerance. Some of them were in fact already implied in the question that made this issue appear on the synodical agenda.

Firstly, it only concerns people 'that err in good faith'. That is why they can be regarded as weak, and not necessarily as having wrong intentions. Although they don't share the common confession of the church, their position is a matter of sincere faith, and not of indifference with regard to God, his Word, or the church. Implicitly, the synod recognises that it is exactly because they want to take the Bible seriously that some people reject infant baptism; the Bible itself is not as clear about this issue as we might think! The decision concerns some people - the general synod cannot and does not give a general ruling that all those who reject infant baptism can be tolerated. It is up to the local church councils to persuade themselves that the concerned members of the congregation err 'in good faith'.

Secondly, this tolerance cannot be exercised regardless of the doctrinal issue at stake. It is only possible if it is not about a 'fundamental issue of truth'. It is interesting to record that 
apparently the issue of infant baptism can be seen as not such a fundamental issue! I will come back to this below.

The third condition is that 'those who err are ready to have themselves better instructed'. Again this emphasises the inequality between those who tolerate and those who are tolerated. Because they are weak, the latter should be ready to enter into discussion with the representatives of the community, that is the local church council. But then again, this council should also be prepared to maintain such communication with the people concerned.

As a consequence, the fourth condition is that these members 'promise not to propagate their opinion'. They have to respect the fact that the local congregation, as well as the national denomination as a whole, wants to maintain and propagate infant baptism unequivocally, and they are supposed to not try and convince other members of the congregation that, from a Biblical perspective, this might be an untenable position.

Under these conditions, a certain degree of tolerance is acceptable for the 1914 general synod - a certain degree of tolerance (I already pointed to its patronising character) that is limited to specific situations (issues and attitudes). It is a limited freedom of opinion, and it certainly does not include an unlimited freedom of speech. This conditional tolerance includes that these members qualify for admission to Holy Supper, let alone that they would be excluded from the community (cf. Koffeman \& Speelman 2010).

But at the same time the synodical decision makes it very clear that it is 'of course, self-evident (note the duplication, LJK) that such members of the congregation will not be eligible for any office in the church in any case, as long as they persist in this opinion'. This condition is hardly surprising. Those who hold an office in the church can be expected to represent the church and its views in all respects in the contacts they have with members of the church community. They should avoid situations in which the sincere loyalty to the church and the dedication - in 'good faith' - to one's own faith convictions are conflicting heavily. This, again, emphasises the conditional character of this tolerance, and the inequality it is based on

\section{Fundamental and non-fundamental faith issues}

The distinction between fundamental and non-fundamental faith issues requires some specific reflection from a historical and a systematic-theological perspective.

It is surprising, indeed, that the synodical decision suggests that the issue of infant baptism is 'non-fundamental' in character. Infant baptism has been practiced for many centuries throughout the Christian community, and it has always been seen as a vital part of the Reformed faith tradition. This is reflected in several Reformed confessional standards. The Heidelberg Catechism (1563) reads:

Q. Should infants, too, be baptised?
A. Yes. Infants as well as adults belong to God's covenant and congregation. Through Christ's blood the redemption from sin and the Holy Spirit, who works faith, are promised to them no less than to adults. Therefore, by baptism, as sign of the covenant, they must be incorporated into the Christian church and distinguished from the children of unbelievers. This was done in the old covenant by circumcision, in place of which baptism was instituted in the new covenant. (Heidelberg Catechism, Sunday 27, Q/A 74)

This endorses the view of the Belgic Confession (1561):

We believe our children ought to be baptised and sealed with the sign of the covenant, as little children were circumcised in Israel on the basis of the same promises made to our children. And truly, Christ has shed his blood no less for washing the little children of believers than he did for adults. Therefore they ought to receive the sign and sacrament of what Christ has done for them, just as the Lord commanded in the law that by offering a lamb for them the sacrament of the suffering and death of Christ would be granted to them shortly after their birth. This was the sacrament of Jesus Christ. Furthermore, baptism does for our children what circumcision did for the Jewish people. That is why Paul calls baptism the 'circumcision of Christ'. (Belgic Confession, Art. 34)

The same view can be found in confessional standards from the Lutheran tradition, like the Augsburg Confession (art. IX) and the Small Catechism of Luther (part IV).

The very fact of an explicit distinction between fundamental and non-fundamental doctrinal issues might seem to be surprising, in a time that the RCN was quite convinced of its interpretation of truth. It is conceivable - but we don't know that H.H. Kuyper, the author of the Report, was aware of The Fundamentals, a set of 90 essays published in 12 books between 1910 and 1915 by the Bible Institute of Los Angeles, a publication that is at the roots of the term 'fundamentalism' as it is now present in public discussion about religion and society.

Karl Barth has convincingly argued that the distinction between fundamental and non-fundamental doctrinal issues is characteristic of 'later Protestant orthodoxy'; the same goes for the doctrine of the verbal inspiration of Scripture (cf. Barth 1956:863-866). Such a concept would be based on the argument that the fundamental articles are to be distinguished from the non-fundamental ones by their contents, in so far as they contain the essential causes and conditions of salvation, by the special emphasis they receive in Scripture, and by their inclusion in the apostolic creed. It is obvious that infant baptism does not meet these criteria.

Barth is known as a fierce opponent of this type of orthodoxy. He basically rejects the aforementioned distinction, because it tends to substitute living faith - that is the actual encounter with God in his Word - with formulas:

In dogmatics, therefore, traditional notions as to what is fundamental or not, central or peripheral, more or less important, have to be suspended, so that they can become a matter for vital new decision by the Word of God itself. (...) Dogma is an 
eschatological idea, to which each particular dogmatic statement is only an approximation, which can neither anticipate nor conceal it. This is a truth which the Church can easily forget, and if it does, the result is that in its preoccupation with mere creeds and dogmas it loses the capacity for confession and the living relationship with true dogma. (...) In dogmatics we cannot presume to know and declare in advance, as a more than hypothetical certainty, what is and what is not fundamental. (Barth 1956:865)

Nevertheless, in the decision of the general synod of the RCN in 1914 this distinction made it possible to tolerate a dissenting view, at least with regard to this specific issue of infant baptism.

\section{The Pacification of 1917}

Tolerance as expressed here is limited to 'members of the congregation'. In a pregnant sentence the report explicitly states that:

this tolerance will, of course, be more extensive with regard to those who are already members of the congregation than with regard to those who want to come to the congregation for the first time (from outside), because the church must take care that it does not admit into its gates enemies of the truth. (Report 1914)

Unintendedly, this sentence sheds some light on the mutual perception of different groups in society at the time, including the Reformed, and on the dominant attitude resulting from it.

In order to evaluate this attitude, it is important to get a picture of the political and social context of the Netherlands one century ago. At that time, relationships in society were complicated and quite tense. For different reasons, different minority groups longed for recognition of their particular identities. Roman Catholics, (orthodox) Reformed protestants, social democrats, and to some extent also liberals were basically living in their own communities, limiting mutual contacts as far as possible. For instance, Reformed Christians would be members of a Reformed political party and a Reformed labour union, they would read Reformed journals, send their children to Reformed schools, buy - if possible whatever they needed in shops owned by other Reformed people, and so on. In a similar way, particularly Roman Catholics and social democrats would live within their own 'pillar'.

The political landscape was complicated; the same four minorities had to find ways to live and work together politically, in spite of their opposite interests and convictions. After the elections of 1913, 25\% of parliament members belonged to the Roman Catholic party, 20\% were protestants together usually referred to at the time as the 'right wing parties'. On the other hand, 36\% belonged to (three different) liberal parties, and $18 \%$ were social democrats, together known as the 'left wing parties'. For decades, a deadlock had frustrated political progress. The left wing parties had been in favour of the introduction of general voting rights (universal suffrage) for all adult male and female citizens for a long time, but that required a change of the Constitution for which they needed a two-thirds majority in Parliament. The right wing parties had strived for decades for the funding of confessional private schools by the government on the same footing as public schools, but in this so-called 'school funding controversy' they also lacked the necessary majority in Parliament. As long as all would want to impose their specific views and practices on society as a whole, nobody would be able to do so. Altogether, this tension was not just a matter of a difficult political agenda; it had a strong impact on society as a whole, with a potential to cause deep rifts among the Dutch population. In order to find a way out, a certain degree of tolerance was required: compromising was a necessity. Freedom and tolerance had to be negotiated.

It was in those very years that this compromise was finally found. After the 1913 elections, the 'extra-parliamentarian' cabinet of Pieter Cort van der Linden had to find a solution for these issues - in a time that it also wanted to prevent the Netherlands from becoming involved in the imminent World War. It succeeded in both respects. The Netherlands maintained its neutrality in international relationships, and a compromise with regard to the political aspirations of the right wing and the left wing parties was found. The leaders of all political parties participated in committees that had to find solutions for both the issue of the universal suffrage and the issue of the school funding controversy at the same time. At the end of the day, they in fact exchanged interests: the left wing obtained universal suffrage; the right wing obtained the equal funding of private and public schools. Both interests are safeguarded in the Constitution up till today, although Dutch society has changed radically in the twentieth century, and tolerance is being challenged today from different perspectives.

This political solution became known as the 'Pacification of 1917', and it would become characteristic of the way tolerance is being strived for in the Netherlands. The designation 'Pacification' is not casual at all; it intendedly refers to the 'Pacification of Ghent of 1576', an important event in the birth history of the Netherlands, when a number of independent Provinces built an alliance in order to support each other mutually: religious tolerance was part and parcel of this alliance. However, historians and political scientists have different views about the significance of this compromise of 1917. Whereas, for instance, Arend Lijphart, sees this as a breakthrough that would determine Dutch political relationships and practices for half a century (cf. Lijphart 1968), Piet de Rooy sees this as an overstatement: he is rather surprised that it took so long before this agreement was formalised politically (cf. De Rooy 2005). But also De Rooy refers to the 'symbolic importance' of the 1917 decision:

It was the recognition of the dissension of Dutch society, exactly in the willingness to tidy away the 'old mess'. Henceforth, the national self-image was 'unity in diversity'. Thus, the idea was given up that a nation could only exist if everybody was the same, a view that made nationalism so dangerous. Instead, the view became prevalent that is was sufficient to accept dissension and to treat each other in a more or less peaceful way. (De Rooy, o.c., author's own translation) 
So, according to De Rooy a certain degree of tolerance has been characteristic of Dutch society for certainly more than a century. In any case, until today social and political life in the Netherlands is characterised to a large extent by the need and the willingness to form coalitions, to work together on a basis of mutual respect of differences in religious and political convictions. This so-called 'polder model' - referring to the need to work together in order to keep the water out of our Lowlands - is challenged again nowadays.

\section{Tolerance?}

How should we interpret the decision of the general synod of 1914 in this social-political context? What does it say about tolerance in this Reformed sector of the Dutch society? Is it a clear proof that things were changing, indeed, both in church and society?

The political decision of 1917, although a breakthrough in a political stalemate, was not at all a principled choice in favour of tolerance as it is understood in Western society nowadays. It rather was a pragmatic solution for a problem that had to be solved politically, in spite of continuing negative mutual views between different parts of plural Dutch society. Until the early 1960s, this would hardly change: only then, linked with growing secularisation and with the increasing awareness of the importance of human rights, societal relationships began to be based on a shared conviction that tolerance is not only a prerequisite for a peaceful society, but that it is a value in itself, as it recognises the fundamental right of freedom of speech and religion.

Similarly, the synodical decision of 1914, although representing an interesting change, was in no way a principled choice in favour of more freedom of thoughts within the church: the conditions as formulated in the decision make that very clear. It rather was a pastoral solution with regard to a specific doctrinal issue that happened to be less clear than desirable. The simple fact that infant baptism is not unequivocally witnessed to in the Bible made it possible and necessary for the general synod to give in a bit - in spite of seemingly clear statements in the authoritative confessional documents. From this perspective as well, 1914 did not mark a watershed: tolerance in doctrine was not at all to become the new standard. On the contrary, in 1926 and in 1944 doctrinal conflicts would disrupt the RCN, and so on issues that - certainly in the 1944 case - could hardly be seen as 'fundamental' faith issues. Only in the 1960s, this would start to change gradually.

So, the synodical decision of 1914 hardly expresses tolerance, and neither does the political decision of 1917. The dominating mood and attitude among those in leadership in church and society - at least as far as the Reformed sector is concerned continued to be characterised by a strong confidence to be right, as opposed to many others who are clearly wrong. Half a century later major change occurred in both respects. And nowadays, a century after 1914 and 1917, new challenges in terms of tolerance have appeared on the Dutch stage.

\section{Costly tolerance - in the church}

It might be helpful to consider the issue of tolerance in the church by characterising it as 'costly'. This connects it with an ecumenical discussion on ethics and ecclesiology as documented in a series of three consultations sponsored by the World Council of Churches in the 1990s. Both fields, ethics and ecclesiology, are at stake in a discussion on tolerance in the church. The aforementioned consultations resulted in reports with the following titles: Costly Unity, Costly Commitment, and Costly Obedience (published together in Best \& Robra 1997).

The emphasis on 'costliness' in these titles refers to the implications of what Bonhoeffer characterised as 'cheap grace' (cf. Bonhoeffer 1994:44f.): forgiveness without repentance, baptism without discipleship. Grace has a price, and unity, commitment, and obedience have a price as well, particularly with regard to their ethical implications:

Moral issues and struggle often represent the line between 'cheap' unity and 'costly' unity. Cheap unity avoids morally contested issues because they would disturb the unity of the church. Costly unity is discovering the churches' unity as a gift of pursuing justice and peace. It is often acquired at a price. (Costly Unity, § 7.6)

Therefore, churches have to work together in this respect:

It becomes increasingly clear that the road to a costly unity leads necessarily through a costly commitment of the churches to one another. (Costly Commitment, § 10)

The third consultation adds:

The obedience to which we are called is often costly. It may require the churches to position themselves in relation to the issues of particular times and places in ways which call for courage, perseverance, and sacrifice. (Costly Obedience, § 4)

In a corresponding way we have to speak today of the need of a 'costly' kind of tolerance in the church. This is what the balance of obedience and freedom is all about. Whereas, a century ago many churches were hardly able to recognise the value of freedom in the church, the opposite might be the case now, at least in quite a few churches in Western Europe. Nowadays, we struggle with the issue of obedience, and therefore discipline:

Given the ambiguity and complexity of so many concrete moral challenges, it is not to be expected that all the members of a particular church, or all church organisations in a particular region, will arrive at the same moral decision in each particular situation. Christian freedom encompasses sincere and serious differences of moral judgment. [7.4.] This observation is not an opening of the door to wholesale moral relativism, however. There are boundaries, and it will always be the case that certain decisions and actions are in contradiction to the nature and purpose of the church and the central teaching of the gospel. (Costly Unity, § 7.3f.)

Costly tolerance in the church presupposes the willingness to accept each other fully, in spite of deeply rooted differences in ethics and doctrine. Costly tolerance is based on the 
recognition of equality as a value in itself, irrespective of power relationships. It is costly because it implies a degree of self-restraint (out of respect for people with other views): I cannot always get it my way.

But costly tolerance does not mean tolerance at all costs. The issue is certainly not that churches should uncritically adopt modern liberal views of individual freedom. Each faith community has the undeniable right and duty to limit tolerance with regard to views and practices that are not compatible with its most pivotal beliefs. That is where church polity has to play its role. If we confess the apostolicity of the Church, we have to safeguard the authenticity of the preaching and witness of the church we belong to, and therefore regulate its doctrinal discipline, particularly regarding its ordained ministers (cf. Koffeman 2014:189). And if we confess the holiness of the Church, we have to safeguard the integrity of the church we are responsible for, and therefore regulate its discipline regarding lifestyle (cf. Koffeman 2014:227ff.). In his aforementioned contributions, Graham Duncan has expressed valuable insights into how, by the time of the Reformation, church discipline 'took on a legalistic and rigid form that militated against its earlier approach', because of 'a misunderstanding of key reformers from the Reforming tradition such as John Calvin and John Knox, who were concerned to build up individuals within the Christian community to become responsible members of society' (Duncan 2010b:1). He does not plead in favour of the abolition of church discipline, not at all, but he advocates an exercise of discipline that is really transformative of individuals and society. I am grateful for the occasion given with this volume to welcome his thorough research in this respect. In my view, it includes what I call costly tolerance in the church, as a permanent process of open communication about life and doctrine. It is not a matter of goodwill, it is not patronising, and it is unconditional. Such tolerance creates the best conditions for a valuable exercise of discipline. In this respect, churches, both in the Netherlands and South Africa, are challenged today.

\section{Costly tolerance - in society}

Basically, a similar approach is necessary with regard to the difficult challenges in society. Nowadays, tolerance is a hot issue in the Netherlands, particularly with regard to the relationships between autochthonous Dutch people and people that have migrated to the Netherlands over the last 50 years. Often this tension is interpreted as religious in character. Migrants and Muslims are easily identified, because the visible presence of Islam in the Netherlands nowadays is a direct consequence of migration. So, it is easy to define the issue as a conflict between Muslims and others. Who exactly the 'others' are, however, is not so clear. In the secularised majority in Dutch society different views can be found in this respect. Some secular thinkers would refer to the 'Jewish Christian heritage' as underlying Dutch secular culture, and would therefore tend to see the Christian minority as their allies in a conflict with 'intolerant' Islam. Others tend to see religion itself as the main problem, and plead in favour of secularism as opposed to all kinds of religion, including Muslims as well as Christians.

In any case, it is this present social and political tension that gives the issue of how to understand and to practice tolerance a new relevance. Society nowadays can no longer afford 'cheap', uncommitted tolerance. It has to learn about the costliness of tolerance. That is what made the aforementioned interreligious and intercontextual conference in Yogyakarta interesting, both for the Indonesian society (the largest Muslim country in the world in terms of population, but with a Christian minority that cannot be neglected) and for the Netherlands. In our Dutch context also costly tolerance is pivotal, as it is in most countries, I assume - and not least in South Africa. Again, it presupposes the willingness to accept each other fully, in spite of deeply rooted differences in worldview and religion, as long as these differences do not lead to violence. It is based on the recognition of equality as a value in itself, irrespective of power relationships. It implies a degree of self-restraint, not out of fear for retaliation but out of respect for people with other views. Unfortunately, it is exactly the risk of retaliation that nowadays burdens a free public discourse about the need of self-restraint.

Costly tolerance does not mean tolerance at all costs. This is true for society as well. Each political community has the right to limit tolerance with respect to views and practices that are not compatible with its most basic convictions regarding freedom and law. To say it a bit paradoxically, part of the price we have to pay for a tolerant society is the willingness not to tolerate intolerance.

\section{Acknowledgements Competing interests}

The author declares that he has no financial or personal relationships which may have inappropriately influenced him in writing this article.

\section{References}

Acta van de Generale Synoden der Gereformeerde Kerken in Nederland, gehouden te 's-Gravenhage 16 juli, 10 september en 17 october 1912 en van 27 october tot 6 november 1914, Zwagers, Rotterdam, NY.

Barth, K., 1956, The Church Dogmatics. Volume I, part 2. The Doctrine of the Word of God, in G.W. Bromiley \& T.F. Torrance (eds.), transl. G.T. Thomson \& H. Knight, T \& T Clark, Edinburgh. Original German version: K. Barth, Die Kirchliche Dogmatik, 1/2, Die Lehre vom Wort Gottes, Evangelischer Verlag A.G., Zollikon-Zürich 1945, 965-968.

Best, T.F. \&. Robra, M., 1997, Ecclesiology and ethics: Ecumenical ethical engagement moral formation and the nature of the church, WCC, Geneva.

Bonhoeffer, D., 1994, The cost of discipleship, 18th ed., transl. R.H. Fuller \& I. Booth, SCM, London, Original German version, D. Bonhoeffer, Nachfolge, Kaiser, München, 1937.

Costly Commitment, 1994, viewed 3 June 2015, from http://www.oikoumene.org/en/ resources/documents/commissions/faith-and-order/vi-church-and-world/ ecclesiology-and-ethics/costly-commitment

Costly Obedience, 1996, viewed 3 June 2015, from http://www.oikoumene.org/en/ resources/documents/commissions/faith-and-order/vi-church-and-world/ ecclesiology-and-ethics/costly-obedience

Costly Unity, 1993, viewed 3 June 2015, from http://www.oikoumene.org/en/ resources/documents/commissions/faith-and-order/vi-church-and-world/ ecclesiology-and-ethics/costly-unity

De Rooy, P., 2005, 'De Pacificatie van 1917', in Historisch Nieuwsblad, Nr 3, viewed 19 February 2015, from http://www.historischnieuwsblad.nl/nl/artikel/6571/depacificatie-van-1917.html 
Dordt Church Order, viewed 27 May 2015, from http://www.ccel.org/creeds/neth-reforder.txt

Duncan, G., 2010a, 'Church discipline - Semper reformanda as the basis for transformation', Journal of Theology for Southern Africa 136:57-75.

Duncan, G., 2010b, 'Church discipline - Semper reformanda in reformation perspective', in HTS Teologiese Studies/Theological Studies 66(1), Art. \#789, 6 pages. http://dx.doi.org/10.4102/hts.v66i1.789

Koffeman, L.J., 2014, In order to serve: An ecumenical introduction to church polity, LIT-Verlag, Zürich.

Koffeman, L.J. \& Speelman, G 2010, 'De gemeenschap verbroken. Uitsluiting uit de religieuze gemeenschap in christendom en islam', in G. de Kruijf \& W. de Jon (eds.), Een lichte last. Protestantse theologen over de kerk, pp. 141-170, Boekencentrum, Zoetermeer.
Lijphart, A., 1968, The politics of accommodation: Pluralism and Democracy in the Netherlands, University of California Press, Berkeley, CA.

Plaisier, A. \&. Koffeman, L.J. (eds.), 2014, The Protestant Church in the Netherlands: Church Unity in the 21st Century. Stories and Reflections, LIT-Verlag, Zürich.

Report 1914, Report written on behalf of the Advisory Committee by Prof. H.H. Kuyper; Acta 1912-1914, bijlage XCVII, 291.

Van Lieburg, F., 2014, Re-understanding the Dordt Church order in its Dutch political, ecclesiastical and cultural context (1559-1816), in A.J. Janssen \& L. Koffeman (eds.), Protestant Church polity in changing contexts I: Ecclesiological and historical contributions. Proceedings of the International Conference, Utrecht, The Netherlands, 7-10 November, 2011, Series: Church Polity and Ecumenism: Global Perspectives, Nr. 2. LIT-Verlag, Zürich, pp. 117-136. 